\title{
Analisis Kinerja Indeks Saham Syariah Indonesia (ISSI) Sebelum dan Selama Pandemi COVID-19
}

\author{
Tito Cayadi Luthfan \\ Universitas Singaperbangsa Karawang \\ 1810631030117@student.unsika.ac.id \\ Nana Diana \\ Universitas Singaperbangsa Karawang \\ nana.diana@fe.unsika.ac.id
}

\begin{abstract}
Abstrak Kinerja indeks saham ISSI di Indonesia sebelum dan selama pandemi COVID-19 dikaji dalam penelitian ini. Harga closing indeks saham ISSI mingguan di Bursa Efek Indonesia digunakan dalam analisis ini. Analisis ini menggunakan dua situasi yang berbeda, yaitu sebelum pandemi COVID-19 dan selama pandemi di Indonesia, untuk mengkaji perubahan kondisi tersebut menggunakan pendekatan penelitian berdasarkan hipotesis. Teknik penelitian analisis deskriptif komparatif digunakan dalam penelitian ini. Data penelitian diperoleh dari sumber sekunder dan diolah menggunakan SPSS 25 dan uji yang digunakan adalah uji Mann-Whitney. Ada perubahan yang tidak signifikan secara statistik pada kinerja return dan risk saham ISSI sebelum dan selama pandemi COVID-19, menurut temuan tersebut. Tingkat return indeks saham ISSI meningkat selama pandemi Covid-19. Uniknya tingkat risk ditemukan juga ikut meningkat.

Kata Kunci Indeks Saham, Stock Return dan Investment Risk
\end{abstract}

\section{PENDAHULUAN}

Pada 2 Maret 2020, Presiden Joko Widodo yang ditemani oleh Menteri Kesehatan mengumumkan telah ditemukannya kasus pertama Covid-19 di Indonesia. Virus corona baru atau novel coronavirus ( $\mathrm{nCoV}$ ) adalah jenis virus corona baru yang menimbulkan penyakit yang bernama COVID-19. Sebelum dikenal sebagai COVID-19, penyakitnya dikenal sebagai virus corona baru 2019 atau 2019-nCoV. Virus corona baru adalah virus baru, tapi mirip dengan keluarga virus yang menyebabkan SARS (Severe Acute Respiratory Syndrome) dan sejumlah influensa biasa. Sampai 30 Desember 2021 sebanyak 4.262.540 kasus telah tercatat di Indonesia dengan 4.114.141 kasus sembuh dan 144.088 meninggal (covid19.go.id). Tidak lama sejak itu pada 9 Maret 2020, World Health Organization (WHO) atau Badan Kesehatan Dunia) secara resmi mendeklarasikan virus corona (COVID-19) sebagai pandemi pada tanggal 9 Maret 2020. Artinya, virus corona telah menyebar secara luas di dunia. Pandemi COVID-19 tidak hanya memakan banyak korban jiwa tapi juga menekan pertumbuhan ekonomi global (Song et al., 2020). Beberapa negara memberlakukan kebijakan Lockdown guna memperlambat penyebaran COVID-19 namun akibatnya kegiatan ekonomi menjadi terhambat. Mulai dari kegiatan produksi, ekspor serta impor. International Monetary Fund (IMF) memproyeksikan pertumbuhan Gross Domestic Product (GDP) global pada tahun 2020 berada pada -3,1\%. Dibandingkan dengan tahun 2019 yang mencapai peningkatan sebesar 2,8\%. 
Pandemi Covid-19 telah berdampak pada beberapa sektor terpenting yang berkontribusi terhadap PDB nasional. Sektor transportasi, pariwisata, dan perdagangan, serta UMKM yang operasionalnya terhambat oleh pembatasan sosial yang diberlakukan Sebelum merebaknya wabah Covid-19, sektor-sektor tersebut memberikan kontribusi yang signifikan terhadap pertumbuhan ekonomi Indonesia (Indarwati, 2021). Namun, penyebaran epidemi covid-19 ke Indonesia telah mengubah kondisi ekonomi negara yang ada. Menurut laporan Badan Pusat Statistik (BPS) salah satu dampak dari pembatasan ini adalah GDP Indonesia mengalami kontraksi sebesar -2,9\% pada tahun 2020. Sedangkan pertumbuhan ekonomi Indonesia mengalami kontraksi sebesar -2,07\%. Angka persentase pengangguran di Indonesia juga meningkat sebesar 2,14\% dibandingkan tahun sebelumnya.

Menurut OJK (Otoritas Jasa Keuangan), total aset bank syariah meningkat 13,23 persen pada 2019 dibandingkan 2018. Pertumbuhan surat berharga naik 47,82 persen (yoy) dari 22,81 persen (yoy) tahun sebelumnya, dan Bank diharapkan dapat menyalurkan dananya ke komponen lain sejalan dengan penyaluran pembiayaan. DPK bank syariah meningkat 11,86 persen year on year pada Desember 2020, dibandingkan dengan peningkatan 12,03 persen pada tahun sebelumnya (yoy). Perlambatan DPK tersebut didorong oleh pergerakan giro yang tumbuh cukup tinggi sebesar 17,44 persen dibandingkan tahun sebelumnya 32,24 persen (yoy). Sementara itu, pertumbuhan DPK dan tabungan meningkat masing-masing sebesar 5,87 persen (yoy) dan 19,61 persen (yoy) dibandingkan tahun sebelumnya yang meningkat sebesar 5,54 persen (yoy) dan 16,45 persen (yoy).

Tabel 1 Indikator Umum Bank Syariah 2019-2020

\begin{tabular}{|c|c|c|c|c|}
\hline \multirow{2}{*}{ Indikator } & \multicolumn{2}{|c|}{ Nominal } & \multicolumn{2}{|c|}{ Year-Over-Year (уоу) } \\
\hline & Des '19 & Des '20 & Des '19 & Des '20 \\
\hline \multicolumn{5}{|c|}{ BUS \& UUS (Rp Milyar) } \\
\hline Total Aset & 524,564 & 593,948 & $9.90 \%$ & $13.23 \%$ \\
\hline Pembiayaan & 355,182 & 383,944 & $10.93 \%$ & $8.10 \%$ \\
\hline Dana Pihak Ketiga & 416,558 & 465,977 & $12.03 \%$ & $11.86 \%$ \\
\hline \multicolumn{5}{|l|}{ BUS (\%) } \\
\hline CAR & 20.59 & 21.64 & 47 & 105 \\
\hline $\mathrm{ROA}$ & 1.73 & 1.40 & 45 & -33 \\
\hline $\mathrm{NOM}$ & 1.92 & 1.46 & 49 & -45 \\
\hline BOPO & 84.45 & 85.55 & -472 & 110 \\
\hline NPF (gross) & 3.23 & 3.13 & -4 & -10 \\
\hline FDR & 77.91 & 76.36 & -62 & -155 \\
\hline
\end{tabular}

Sumber: Otoritas Jasa Keuangan (OJK)

Pandemi COVID-19 juga memiliki dampak terhadap pasar modal Indonesia, pada tahun 2020 Bursa Efek Indonesia (BEI) telah menerapkan trading halt sebanyak 7 kali. Pasar modal menghubungkan korporasi dan institusi lain (misalnya) yang membutuhkan dana publik untuk pengembangan perusahaan, ekspansi, penambahan modal operasional, dan keperluan lainnya dengan pihak-pihak yang ingin mendukungnya. Untuk mendapatkan sumber, perusahaan atau lembaga menerbitkan saham atau instrumen utang, dan komunitas investor mendanai perusahaan atau lembaga secara langsung atau melalui reksa dana di pasar modal. Akibatnya, pasar modal memainkan peran penting dalam perekonomian suatu negara (Nurhaliza, 2021). 


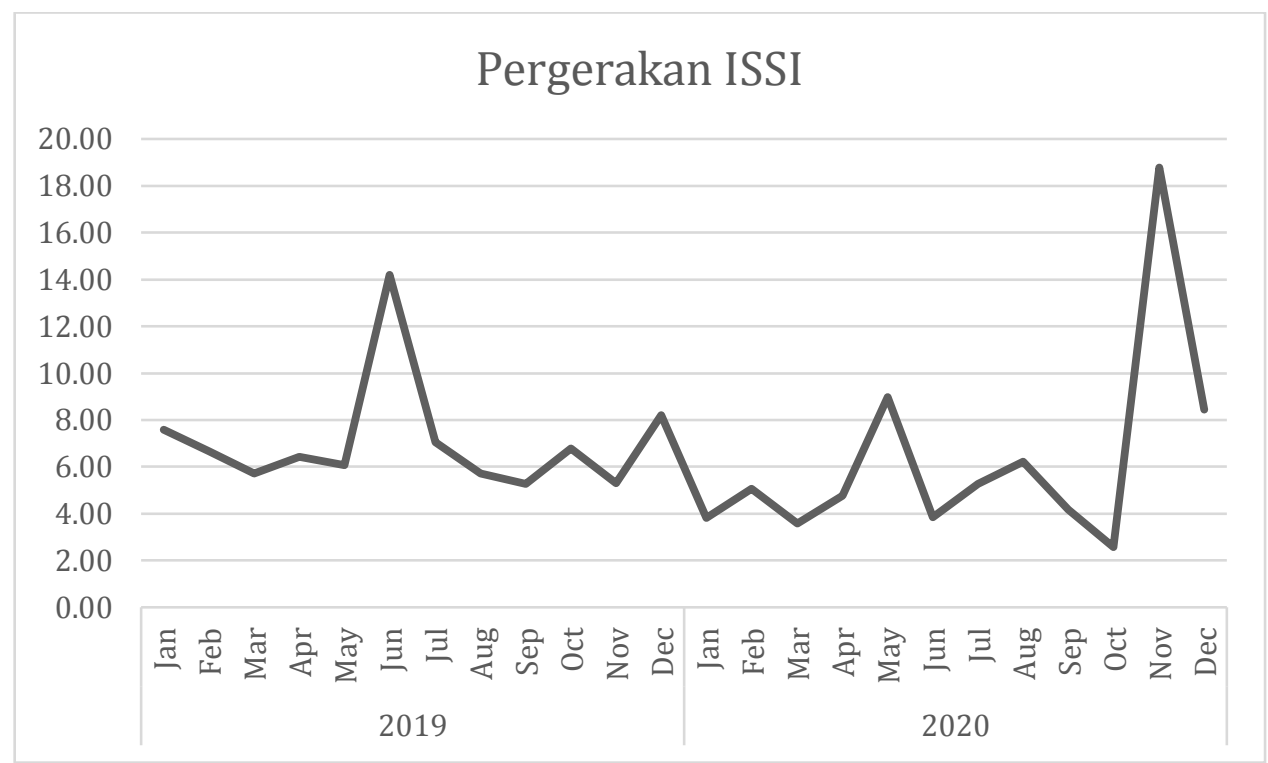

Gambar 1.1. Pergerakan nilai ISSI, Bursa Efek Indonesia

Namun, ISSI (Indeks Saham Syariah Indonesia) menawarkan keunggulan dibandingkan IHSG (Indeks Harga Saham Gabungan), salah satunya adalah utang berbasis bunga tidak dapat melebihi 45 persen dari total aset perusahaan, sehingga memungkinkan untuk menghadapi badai ketidakpastian yang dihasilkan. oleh pandemi ini. ISSI adalah indeks komposit ekuitas syariah yang terdaftar di BEI yang memulai debutnya pada 12 Mei 2011. ISSI merupakan indikator kinerja pasar saham syariah Indonesia.

Berdasarkan fenomena-fenomena yang telah tertera di atas, penelitian ini bertujuan untuk mengkaji perbandingan kinerja risk dan return ISSI ditengah-tengah pandemi COVID-19. Peneliti kemudian memilih judul penelitian "Analisis Kinerja Indeks Saham Syariah Indonesia (ISSI) Sebelum dan Selama Pandemi COVID-19”.

\section{LANDASAN TEORI}

\section{Indeks Saham}

Menurut Bursa Efek Indonesia (BEI) Indeks saham adalah ukuran statistik yang mencerminkan keseluruhan pergerakan harga atas sekumpulan saham yang dipilih berdasarkan kriteria dan metodologi tertentu serta dievaluasi secara berkala. Indeks saham memiliki beberapa manfaat yaitu untuk mengukur sentimen pasar, sebagai proksi untuk kelas aset pada alokasi asset, dijadikan produk investasi pasif seperti Reksa Dana Indeks, dan sebagai proksi dalam mengukur dan membuat model pengembalian investasi (return), risiko sistematis, dan kinerja yang disesuaikan dengan risiko.

\section{Saham}

Saham adalah tanda bukti kepemilikan perusahaan. Pemilik saham disebut juga pemegang saham (shareholder atau stockholder). Bukti bahwa seseorang atau pihak dapat dianggap sebagai pemegang saham apabila seseorang atau suatu pihak sudah tercatat sebagai pemegang saham dalam buku yang disebut daftar pemegang saham (Samsul, 2015). Sedangkan menurut Fahmi (2013) saham adalah bukti kepemilikan modal/dana Anda pada suatu perusahaan kertas, dengan nilai nominal, nama 
perusahaan, serta penjelasan hak dan kewajiban kepada masing-masing pemegang, serta barang yang siap dijual.

\section{Stock Return}

Return saham merupakan hasil yang diperoleh dari investasi. Return dapat berupa return realisasi yang sudah terjadi atau return ekspektasi yang belum terjadi tetapi yang diharapkan akan terjadi dimasa mendatang. Return realisasi (realized return) merupakan return yang telah terjadi. Return realisasi dihitung menggunakan data historis. Return realisasi atau return historis ini juga berguna sebagai dasar penentuan return ekspektasi (expected return) dan risiko di masa dating. Return ekspektasi (expected return) adalah return yang diharapkan akan diperoleh oleh investor di masa mendatang (Jogiyanto, 2017). Return saham menurut Fahmi (2014) keuntungan yang dibuat oleh perusahaan, individu, dan institusi sebagai hasil dari kebijakan investasi mereka. Ada hubungan erat antara risiko dan pengembalian di dunia, yang berarti bahwa jika risikonya tinggi, pengembalian (keuntungan) juga akan tinggi, dan sebaliknya jika pengembaliannya rendah, risikonya juga akan rendah.

\section{Investment Risk}

Risiko investasi adalah perbedaan potensial antara pengembalian aktual dan yang diharapkan. Risiko pasar adalah proksi untuk risiko investasi (Musthafa, 2017). Risiko diklasifikasikan menjadi dua jenis: Risiko Sistematis (Systematic Risk) dan Risiko Tidak Sistematis (Unsystematic Risk). Risiko Sistematis mengacu pada bagian risiko keamanan yang tidak dapat dikurangi dengan membentuk portofolio, sedangkan Risiko Tidak Sistematis mengacu pada bagian risiko keamanan yang dapat dihilangkan dengan membentuk portofolio yang terdiversifikasi dengan baik. Risiko sering dikaitkan dengan penyimpangan atau penyimpangan dari hasil yang diharapkan.

\section{Hipotesis}

Sebuah hipotesis adalah solusi sementara untuk menjawab tantangan suatu penelitian (Sugiyono, 2017). Berdasarkan pernyataan tersebut, dapat disimpulkan bahwa hipotesis adalah rumusan tanggapan sementara untuk suatu masalah yang dimaksudkan untuk menjelaskan dan juga dapat mengarah pada pemeriksaan dan penelitian tambahan. Hipotesis dalam penelitian ini mengacu kepada hasil perhitungan return dan risk indeks saham ISSI yang akan diuji beda dengan menggunakan uji Independent Sample T-test. Rumusan hipotesis yang digunakan dalam penelitian ini sebagai berikut:

H0 : Tidak terdapat perbedaan yang signifikan atas return dan risk saham indeks ISSI selama pandemi COVID-19

H1 : Terdapat perbedaan yang signifikan atas return dan risk saham indeks ISSI selama pandemi COVID-19

\section{METODOLOGI PENELITIAN \\ Metode Penelitian}

Penelitian ini bersifat analisis deskriptif komparatif yaitu meneliti Stock Return dan Investment Risk. Data yang digunakan dalam penelitian ini adalah data sekunder yang berupa closing price mingguan dari ringkasan Indeks Saham Syariah Indonesia (ISSI) mulai dari bulan Maret tahun 2019 sampai dengan bulan Desember 2020 yang 
dikumpulkan dengan menggunakan metode dokumentasi dan tinjauan pustaka. Penelitian ini menggunakan metode data kuantitatif, dimana data yang digunakan dalam penelitian berupa angka dan perhitungan menggunakan metode statistik yang dibantu dengan program SPSS 25. Sumber data diperoleh dari website resmi Bursa Efek Indonesia (BEI). Metode analisis yang digunakan dalam penelitian ini adalah analisis regresi berganda.

\section{Teknik Analisis Data}

1. Tingkat Stock Return

Tingkat pengembalian saham dapat dihitung dengan menghitung hasil bagi antara selisih harga saham periode tahun depan dengan harga saham periode saat ini dibagi harga saham periode saat ini dengan rumus:

$\mathrm{R}=$ return saham

$$
R=\frac{D t+\left(P_{t}-P_{t-1}\right)}{P_{(t-1)}}
$$

$\mathrm{Dt}=$ dividen saham pada peiode $\mathrm{t}$

$\mathrm{Pt}=$ harga saham pada periode $\mathrm{t}$

2. Tingkat Investment Risk

Besaran risiko investasi diukur dari besaran standar deviasi dari return yang diharapkan. Deviasi standar merupakan akar kuadrat dari varians, yang yang menunjukkan seberapa besar penyebaran variabel random di antara rata-ratanya; semakin besar penyebarannya, semakin besar varians atau deviasi standar investasi tersebut.

$$
\begin{array}{ll} 
& \multicolumn{1}{c}{\sigma^{2}=\sum\left[R_{i}-E(R)\right]^{2} \mathrm{pr}_{i}} \\
& \sigma=\left(\sigma^{2}\right)^{1 / 2} \\
\sigma 2 & =\text { varians return } \\
\sigma & =\text { standar deviasi } \\
\mathrm{E}(\mathrm{R}) & =\text { returnyang diharapkan dari suatu sekuritas } \\
R i & =\text { returnke-i yang mungkin terjadi } \\
\text { pri } & =\text { probabilitas kejadian return ke-i }
\end{array}
$$

3. Uji Normalitas

Uji normalitas menentukan apakah residu yang terkumpul memiliki distribusi normal. Uji Kolmogorov-Smirnov digunakan dalam uji statistik ini, dan interpretasi hasilnya adalah jika nilai signifikan lebih besar dari 0,05 maka residual berdistribusi normal, dan jika nilai signifikan lebih kecil dari 0,05 maka data penelitian tidak terdistribusi normal (Sugiyono, 2017). Tujuan dari uji normalitas adalah untuk mengetahui apakah model regresi, faktor pengganggu, atau residual berdistribusi normal (Ghozali, 2018).

4. Uji Independent Samples T-Test

Uji Independent Samples T-Test digunakan untuk membandingkan kinerja dan risiko saham sebelum dan sesudah pandemi COVID-19. Tes ini membandingkan rata-rata dua kelompok data independen. Uji Independent Samples T-Test dilakukan dengan membandingkan nilai rata-rata kedua sampel dengan standar error selisih rerata kedua sampel. Tujuan dari tes ini adalah untuk membandingkan rata-rata dari dua kelompok yang tidak berhubungan. Untuk melihat apakah ada perbedaan rata-rata dari dua sampel yang tidak berhubungan, digunakan uji Independent Samples T-Test (Ghozali, 2016). 


\section{Uji Mann-Whitney}

Uji Mann-Whitney dapat digunakan untuk data statistik minimal, artinya dapat digunakan untuk data ordinal, interval, atau rasio. Ketika jenis data independen yang akan dievaluasi adalah interval atau rasio, uji Mann-Whitney digunakan untuk statistik data dua sampel. Karena data dalam penelitian ini adalah data tes hasil belajar yang diterima dari kelas eksperimen dan kelas kontrol dengan data interval siaran, maka peneliti dapat memanfaatkan uji Mann-Whitney (Lestari \& Yudhanegara, 2015).

\section{HASIL PENELITIAN}

\section{Uji Statistik Deskriptif}

Tabel 2 Hasil uji statistik deskriptif

\section{Descriptive Statistics}

\begin{tabular}{l|r|r|r|r|r} 
& N & Minimum & Maximum & \multicolumn{1}{c}{ Mean } & Std. Deviation \\
\hline Return & 86 & -.022 & .141 & .00374 & .017988 \\
\hline Risk & 86 & .250 & 7.920 & 1.49791 & 1.234588 \\
\hline Valid N (listwise) & 86 & & & & \\
\hline
\end{tabular}

Berdasarkan hasil statistik deskriptif variabel penelitian yaitu meliputi nilai minimum dan maksimum, rata-rata (mean), dan standar deviasi :

- Stock Return

\section{Uji Normalitas}

Tabel 3 Hasil uji normalitas One-Sample Kolmogorov Smirnov

One-Sample Kolmogorov-Smirnov Test

\begin{tabular}{|c|c|c|c|}
\hline & & Return & Risk \\
\hline$N$ & & 86 & 86 \\
\hline \multirow[t]{2}{*}{ Normal Parameters ${ }^{\mathrm{a}, \mathrm{b}}$} & Mean & .00374 & 1.49791 \\
\hline & Std. Deviation & .017988 & 1.234588 \\
\hline \multirow[t]{3}{*}{ Most Extreme Differences } & Absolute & .248 & .202 \\
\hline & Positive & .248 & .202 \\
\hline & Negative & -.188 & -.164 \\
\hline Test Statistic & & .248 & .202 \\
\hline Asymp. Sig. (2-tailed) & & $.000^{\mathrm{c}}$ & $.000^{\mathrm{c}}$ \\
\hline
\end{tabular}

a. Test distribution is Normal.

b. Calculated from data.

c. Lilliefors Significance Correction.

Berdasarkan tabel diatas dapat dilihat bahwa nilai signifikansi berada dibawah 0,05 yang berarti data tidak berdistribusi normal. Dalam pengujian hipotesis nol yang menyatakan bahwa tidak ada perbedaan yang sesungguhnya antara kedua kelompok data dan dimana data tersebut diambil dari sampel yang tidak saling terkait, kita dapat melakukan 
pengujian Mann-Whitney. Pengujian ini disebut juga pengujian U, karena untuk menguji hipotesis nol, kasus dihitung angka statistik yang disebut U (Sriwidadi, 2011).

\section{Uji Mann-Whitney U}

Tabel 2 Hasil uji Mann-Whitney U

\begin{tabular}{|c|c|c|c|c|}
\hline \multicolumn{5}{|c|}{ Ranks } \\
\hline & VAR00001 & $N$ & Mean Rank & $\begin{array}{l}\text { Sum of } \\
\text { Ranks }\end{array}$ \\
\hline \multirow[t]{3}{*}{ Return } & Sebelum Pandemi & 42 & 41.92 & 1760.50 \\
\hline & Selama Pandemi & 44 & 45.01 & 1980.50 \\
\hline & Total & 86 & & \\
\hline \multirow[t]{3}{*}{ Risk } & Sebelum Pandemi & 42 & 40.10 & 1684.00 \\
\hline & Selama Pandemi & 44 & 46.75 & 2057.00 \\
\hline & Total & 86 & & \\
\hline
\end{tabular}

Test Statistics ${ }^{\mathrm{a}}$

\begin{tabular}{lr|r} 
& \multicolumn{1}{c}{ Return } & \multicolumn{1}{c}{ Risk } \\
\hline Mann-Whitney U & 857.500 & 781.000 \\
\hline Wilcoxon W & 1760.500 & 1684.000 \\
\hline Z & -.583 & -1.236 \\
\hline Asymp. Sig. (2-tailed) & .560 & .217 \\
\hline
\end{tabular}

a. Grouping Variable: VAR00001

Bisa dilihat dari tabel diatas bahwa Asymp. Sig. (2-tailed)/signifikansi nilainya adalah 0,560 untuk variable Return dan 0.217 untuk Risk. Karena nilai signifikansinya diatas 0,05 maka H0 diterima. Yaitu tidak terdapat perbedaan yang signifikan untuk tingkat Return dan Risk Indeks Saham Syariah Indonesia (ISSI).

\section{KESIMPULAN}

Berdasarkan temuan penelitian, tidak terdapat perubahan kinerja yang signifikan pada indeks saham ISSI sebelum dan sesudah pandemi COVID-19. Hal ini terlihat pada kinerja return saham ISSI pada masa pandemi yang mengalami kenaikan yang tidak signifikan walau seluruh perekonomian dunia mengalami penurunan selama masa pandemi. Jika diperhatikan tingkat risikonya, saham ISSI memiliki tingkat risiko yang lebih tinggi pula namun tidak signifikan dibandingkan dengan sebelum pandemi COVID-19 karena perekonomian Indonesia mengalami penurunan. Ditopangnya tingkat risiko saham ini mungkin karena kebijakan merger bank syariah milik pemerintah pada bulan Juli 2020.

\section{DAFTAR PUSTAKA}

Fahmi, I. (2013). Analisis Laporan Keuangan. Alfabeta.

Fahmi, I. (2014). Manajemen Keuangan Perusahaan Dan Pasar Modal (1st ed.). Mitra Wacana Media. 
JURNAL EKONOMI \& EKONOMI SYARIAH

Jurnal Ekonomi \& Ekonomi Syariah Vol 5 No 1, Januari 2022

E-ISSN : 2599-3410 | P-ISSN : 2614-3259

DOI : https://doi.org/10.36778/jesya.v3i1.642

Ghozali, I. (2016). Aplikasi Analisis Multivariete Dengan Program IBM SPSS 23 (8th ed.).

Universitas Diponegoro.

Ghozali, I. (2018). Aplikasi Analisis Multivariate dengan Program IBM SPSS (Vol. 490). Badan

Penerbit Universitas Diponegoro.

Indarwati, A. S. (2021). The Impact of COVID-19 on the Indonesian Economy. International

Journal of Innovative Science and Research Technology, 6(1), 1513-1516.

Jogiyanto, H. (2017). Teori Portofolio dan Analisis Investasi Edisi 11 (11th ed.). BPFE.

Lestari, K. E., \& Yudhanegara, M. R. (2015). Penelitian Pendidikan Matematika. PT Refika

Aditama.

Musthafa. (2017). Manajemen keuangan (1st ed.). ANDI.

Nurhaliza, S. (2021, May 14). Apa Itu Pasar Modal? Cek Yuk Fungsi, Contoh dan Manfaatnya. www.idx.co.id

Samsul, M. (2015). Pasar Modal dan Manajemen Portofolio (2nd ed.). Erlangga.

Song, L., -Corden, A., Au;, Y., Zhou, A.-C., \& Zhou, Y. (2020). The COVID-19 Pandemic and Its

Impact on the Global Economy: What Does It Take to Turn Crisis into Opportunity?

Sriwidadi, T. (2011). PENGGUNAAN UJI MANN-WHITNEY PADA ANALISIS PENGARUH

PELATIHAN WIRANIAGA DALAM PENJUALAN PRODUK BARU . BINUS BUSINESS

REVIEW, 2(2), 751-762.

Sugiyono. (2017). Metode Penelitian Kuantitatif, Kualitatif, dan R\&D. Alfabeta, CV. 